\title{
Effects of Astragalus polysaccharides on P-glycoprotein efflux pump function and protein expression in $\mathrm{H} 22$ hepatoma cells in vitro
}

\author{
Qing E Tian ${ }^{1,2,3}$, Huan De Li ${ }^{1 *}$, Miao Yan ${ }^{1}$, Hua-Lin Cai ${ }^{1}$, Qin-You Tan ${ }^{1}$ and Wen-Yuan Zhang ${ }^{1}$
}

\begin{abstract}
Background: Astragalus polysaccharides (APS) are active constituents of Astragalus membranaceus. They have been widely studied, especially with respect to their immunopotentiating properties, their ability to counteract the side effects of chemotherapeutic drugs, and their anticancer properties. However, the mechanism by which APS inhibit cancer and the issue of whether that mechanism involves the reversal of multidrug resistance (MDR) is not completely clear. The present paper describes an investigation of the effects of APS on P-glycoprotein function and expression in $\mathrm{H} 22$ hepatoma cell lines resistant to Adriamycin (H22/ADM).
\end{abstract}

Methods: H22/ADM cell lines were treated with different concentrations of APS and/or the most common chemotherapy drugs, such as Cyclophosphamid, Adriamycin, 5-Fluorouracil, Cisplatin, Etoposide, and Vincristine. Chemotherapeutic drug sensitivity, P-glycoprotein function and expression, and MDR1 mRNA expression were detected using MTT assay, flow cytometry, Western blotting, and quantitative RT-PCR.

Results: When used alone, APS had no anti-tumor activity in H22/ADM cells in vitro. However, it can increase the cytotoxicity of certain chemotherapy drugs, such as Cyclophosphamid, Adriamycin, 5-Fluorouracil, Cisplatin, Etoposide, and Vincristine, in H22/ADM cells. It acts in a dose-dependent manner. Compared to a blank control group, APS increased intracellular Rhodamine-123 retention and decreased P-glycoprotein efflux function in a dose-dependent manner. These factors were assessed $24 \mathrm{~h}, 48 \mathrm{~h}$, and $72 \mathrm{~h}$ after administration. APS down regulated P-glycoprotein and MDR1 mRNA expression in a concentration-dependent manner within a final range of $0.8-500 \mathrm{mg} / \mathrm{L}$ and in a time-dependent manner from $24-72 \mathrm{~h}$.

Conclusion: APS can enhance the chemosensitivity of H22/ADM cells. This may involve the downregulation of MDR1 mRNA expression, inhibition of P-GP efflux pump function, or both, which would decrease the expression of the MDR1 protein.

Keywords: Astragalus polysaccharides, Multidrug resistance, P-glycoprotein

\section{Background}

Cancer is as a major public health problem worldwide [1]. The World Health Organization predicts that, by 2030, an estimated 21.4 million new cases of cancer and 13.2 million cancer deaths will occur annually [2]. Surgery, radiation, chemotherapy, and endocrine therapy are the standard cancer therapies [3]. For advanced

\footnotetext{
*Correspondence: lihuande1953@126.com

'Clinical Pharmacy and Pharmacology Research Institute, The Second Xiangya Hospital, Central South University, 139 Renmin Middle Road, Changsha, Hunan 410011, China

Full list of author information is available at the end of the article
}

tumors, chemotherapy is the treatment of choice. Although these drugs are effective, they are associated with severe adverse events and drug resistance, especially multidrug resistance (MDR) [4].

Drug resistance involves many mechanisms. MDR is the leading cause of treatment failure in cancer therapy. Once MDR emerges, chemotherapy becomes ineffective. High doses of drugs are required to overcome resistance, but this has toxic effects in the patient and can increase resistance further [5]. One of the underlying mechanisms of MDR is cellular overproduction of P-glycoprotein (P- GP), which acts as an efflux pump for various anticancer drugs. P-GP is encoded by the MDR1 gene. P-GP 
overexpression has become a therapeutic target for circumventing MDR. One strategy is to co-administer efflux pump inhibitors, but such reversal agents might increase the side effects of chemotherapy by blocking physiological anticancer drug efflux from normal cells. Although many efforts to overcome MDR have been made using first- and second-generation reversal agents, including drugs already in clinical use for other conditions (e.g. verapamil, cyclosporine A, quinidine) and analogues of first-generation drugs (e.g. dexverapamil, valspodar, cinchonine), few significant advances have been made. Clinical trials with third generation modulators (e.g. biricodar, zosuquidar, and laniquidar) specifically developed for MDR reversal are ongoing. The results, however, are not encouraging and it may be that no perfect reverser currently exists [6].

Traditional Chinese medicine (TCM) and herbal medicines in particular have been used in the treatment of cancer for thousands of years in China, Japan, South Korea, and other Asian countries. These medicines are widely accepted as current forms of complementary and alternative cancer treatments in the United States and Europe [7,8]. Experiments have shown that TCM plays an anticancer role by inducing apoptosis and differentiation, enhancing immune response, inhibiting angiogenesis, and reversing MDR [9]. TCM has great advantages in terms of increasing the sensitivity of chemo-therapeutics, reducing the side effects and complications associated with chemotherapy, and improving both patient quality of life and survival time [10]. In the search for new cancer therapeutics with low toxicity and few side effects, TCM shows promise [11].

The dried root of Astragalus membranaceus has a long history of medicinal use in TCM. It is traditionally prepared as a tonic that can improve the functioning of the lungs, adrenal glands, and the gastrointestinal tract, increase metabolism, promote healing, and reduce fatigue [12]. The active pharmacological constituents of Astragalus membranaceus include various polysaccharides, saponins, flavonoids, and L-arginine and L-canavanine $[13,14]$. Among these, Astragalus polysaccharides (APS) has been most widely studied, mainly with respect to its immunopotentiating properties, its ability to counteract the side effects of chemotherapeutic drugs, and its anticancer activity [12,14-24]. However, the anti-cancer mechanism of APS and the issue of whether or not it involves the reversal of multi-drug resistance are not completely clear. Reports indicate that Astragalus membranaceus compound preparations "Changweiqing" and "Jiexinkang" can reverse multidrug resistance and that "preventing recurrence formula for UC" can inhibit the expression of P-gp in colon tissue [25-27]. APS is the main active ingredient of Astragalus membranaceus, and it is worthy of further investigation.
The present study focused on investigating the effects and relevant mechanisms of APS on P-GP function and expression in H22 hepatoma cell lines resistant to Adriamycin (H22/ADM).

\section{Methods}

Main reagents

APS (20000-60000 mol/L) was purchased from Shanxi Undersun Biomedtech Co. Ltd.). Cyclophosphamid (MTX), Adriamycin (ADM), 5-fluorouracil (5-Fu), cisplatin (DDP), etoposide (VP-16), vincristine (VCR), verapamil (VER), and rifampicin (RFP) were purchased from the National Institutes for Food and Drug Control). A two-step immunohistochemistry detection kit PV9000; Rhodamine123 (Rh-123); TaKaRaRNA PCRI Kit (AMV) Ver3.0; and TRIZOL reagent were purchased from SIGMA Corporation. Goat anti-mouse IgG and fluorescein-affinity pure goat anti-rabbit IgG were purchased from Jackson ImmunoResearch Laboratories. Oligonucleotides and reagents for PCR assay were purchased from SIGMA Corporation.

\section{Cell lines and culture conditions}

H22/ADM cell lines purchased from Beijing Cowin Biotech Co. Ltd were incubated in medium containing $1 \mathrm{mg} / \mathrm{L}$ $\mathrm{ADM}$ to maintain its resistant characteristics. We kept H22/ADM cells in medium without ADM for 2 weeks before using these cells. The cells were cultured at $37^{\circ} \mathrm{C}$ in $5 \% \mathrm{CO}_{2}$ with $100 \%$ humidity in RPMI1640 medium (Gibco/ BRL, Bethesda, MD, U.S.) supplemented with $10 \%$ heatinactivated fetal bovine serum (FBS) (Sijiqing, Hangzhou, China), $100 \mathrm{U} / \mathrm{ml}$ penicillin, $100 \mathrm{U} / \mathrm{ml}$ streptomycin.

\section{MTT assay for detection of H22/ADM cell proliferation}

For cell growth and viability assays, $5 \times 10^{4} / \mathrm{ml} \mathrm{H} 22 /$ ADM cells were plated into 96 well cell culture plates (Costar, Charlotte, NC, U.S.) at $190 \mu \mathrm{l}$ per well. After $24 \mathrm{~h}$ of incubation, they were divided into ten groups of six parallel wells each. One group contained $200 \mu \mathrm{l}$ culture medium and served as a negative control group. Another group contained $10 \mu \mathrm{l}$ 0.9\% normal saline (NS) and served as a solvent control group. Three more groups contained DDP $(0.1 \mathrm{mg} / \mathrm{L}, 1.0 \mathrm{mg} / \mathrm{L}$, and $10 \mathrm{mg} / \mathrm{L})$ and served as positive control groups. The remaining five experimental groups received different final concentrations of APS $(0.8 \mathrm{mg} / \mathrm{L}, 4 \mathrm{mg} / \mathrm{L}, 20 \mathrm{mg} / \mathrm{L}, 100 \mathrm{mg} / \mathrm{L}$, and $500 \mathrm{mg} / \mathrm{L})$. After incubation for $24 \mathrm{~h}, 10 \mu \mathrm{l}$ MTT solution $\left(5 \mathrm{mg} / \mathrm{ml}\right.$ ) was added to each well at $37^{\circ} \mathrm{C}$ in the dark and allowed to incubate for at least $4 \mathrm{~h}$. Formazan crystals were solubilized in $150 \mu \mathrm{l}$ dimethyl sulfoxide (DMSO) in every well, gently swinging $10 \mathrm{~min}$. The optical density (OD) was read at $540 \mathrm{~nm}$ and $490 \mathrm{~nm}$ using a plate reader (Model 550; Bio-Rad, Tokyo, Japan). Relative inhibition of cell growth was expressed as follows: 
Percentage $(\%)=(1-[\mathrm{OD}]$ test $/[\mathrm{OD}]$ control $) \times 100 \%$ [28]. Half inhibitory concentration $\left(\mathrm{IC}_{50}\right)$ is calculated by linear regression equation. Each assay was repeated three times.

\section{MTT assay of the sensitivity of H22/ADM cells to chemotherapeutic drugs}

For cell growth and viability assays, $5 \times 10^{4} / \mathrm{ml} \mathrm{H} 22 /$ ADM cells were plated into 96 well cell culture microplates, $100 \mu \mathrm{l}$ per well, respectively. After $6 \mathrm{~h}$ of incubation, the cells were divided into seven groups of six parallel wells each. One group received $200 \mu$ l culture medium. This served as a control group. The other groups received $10 \mu \mathrm{l}$ volumes of different final concentrations of APS $(0.8 \mathrm{mg} / \mathrm{L}, 4 \mathrm{mg} / \mathrm{L}, 20 \mathrm{mg} / \mathrm{L}, 100 \mathrm{mg} / \mathrm{L}$, $500 \mathrm{mg} / \mathrm{L}$ ). The cells that received these quantities of APS served as five experimental groups [29-31]. After incubation for $24 \mathrm{~h}$, the medium was discarded and replaced with $190 \mu \mathrm{l}$ of fresh medium per well. Then $10 \mu \mathrm{l}$ the following concentrations of chemotherapy drugs were added into each well: ADM $(0.625 \mu \mathrm{g} / \mathrm{ml}$, $1.25 \mu \mathrm{g} / \mathrm{ml}, 2.5 \mu \mathrm{g} / \mathrm{ml}, 5 \mu \mathrm{g} / \mathrm{ml}, 10 \mu \mathrm{g} / \mathrm{ml}), 5-\mathrm{Fu}(25 \mu \mathrm{g} / \mathrm{ml}$, $50 \mu \mathrm{g} / \mathrm{ml}, 100 \mu \mathrm{g} / \mathrm{ml}, 200 \mu \mathrm{g} / \mathrm{ml}, 400 \mu \mathrm{g} / \mathrm{ml})$, DDP $(5 \mu \mathrm{g} / \mathrm{ml}, 10 \mu \mathrm{g} / \mathrm{ml}, 20 \mu \mathrm{g} / \mathrm{ml}, 40 \mu \mathrm{g} / \mathrm{ml}, 80 \mu \mathrm{g} / \mathrm{ml})$, $\mathrm{VP}-16(75 \mu \mathrm{g} / \mathrm{ml}, 150 \mu \mathrm{g} / \mathrm{ml}, 300 \mu \mathrm{g} / \mathrm{ml}, 600 \mu \mathrm{g} / \mathrm{ml}$, $1200 \mu \mathrm{g} / \mathrm{ml}), \operatorname{VCR}(1.25 \mu \mathrm{g} / \mathrm{ml}, 2.5 \mu \mathrm{g} / \mathrm{ml}, 5 \mu \mathrm{g} / \mathrm{ml}$, $10 \mu \mathrm{g} / \mathrm{ml}, 20 \mu \mathrm{g} / \mathrm{ml})$, CTX $(100 \mu \mathrm{g} / \mathrm{ml}, 200 \mu \mathrm{g} / \mathrm{ml}$, $400 \mu \mathrm{g} / \mathrm{ml}, 800 \mu \mathrm{g} / \mathrm{ml}, 1600 \mu \mathrm{g} / \mathrm{ml})$. After incubation for $24 \mathrm{~h}, 10 \mu \mathrm{l}$ MTT solution $(5 \mathrm{mg} / \mathrm{ml}$ ) was added into each well at $37^{\circ} \mathrm{C}$ in the dark for at least $4 \mathrm{~h}$. Formazan crystals were solubilized in $150 \mu \mathrm{l}$ DMSO in every well with 10 min of gentle mixing, and the OD was read at a wavelength of $540 \mathrm{~nm}$ and $490 \mathrm{~nm}$ using a plate reader. Relative inhibition of cell growth was expressed as follows: Percentage $(\%)=(1-[\mathrm{OD}]$ test $/[\mathrm{OD}]$ control $) \times$ $100 \%$ [28]. IC50 was calculated using a linear regression equation. Each assay was repeated three times.

\section{Rh-123 accumulation assay}

The efflux activity of P-GP was determined by measuring the accumulation of the fluorescent P-GP probe Rh-123 as described by Collett A et al. [32]. In brief, H22/ADM cells were incubated with RPMI1640 medium, and then RPMI1640 medium (was used as a blank control group), APS (final concentrations $0.8 \mathrm{mg} / \mathrm{L}, 4 \mathrm{mg} / \mathrm{L}$, $20 \mathrm{mg} / \mathrm{L}, 100 \mathrm{mg} / \mathrm{L}, 500 \mathrm{mg} / \mathrm{L}$ ), VER (P-GP antagonist, was used as positive control) $10 \mu \mathrm{mol} / \mathrm{L}$, RFP (P-GP inducer, was used as positive control) $10 \mu \mathrm{mol} / \mathrm{L}$ for $24 \mathrm{~h}$, $48 \mathrm{~h}$, and $72 \mathrm{~h}$ before Rh-123 experiments took place. Then cells were treated with trypsin digestion, centrifugation $700 \times \mathrm{g}, 5 \mathrm{~min}, 4^{\circ} \mathrm{C}$, adjusted to $1 \times 10^{6} / \mathrm{ml}$ of cell suspension, and added to $1.5 \mathrm{ml} \mathrm{EP}$ tube, $0.5 \mathrm{ml} /$ tube, $\mathrm{Rh}-123$ was added to cells in the final concentration of $500 \mu \mathrm{mol} / \mathrm{L}$, followed by incubation at $37^{\circ} \mathrm{C}$ in $5 \% \mathrm{CO}_{2}$ incubator for $60 \mathrm{~min}$. Each group included six parallel EP tubes. After this incubation period, the cells were washed twice (cold PBS, $4^{\circ} \mathrm{C}$; centrifugation $700 \times \mathrm{g}, 5 \mathrm{~min}, 4^{\circ} \mathrm{C}$ ) and fixed (cell fix, $0.5 \mathrm{ml}$ ). All samples were analyzed using flow cytometry.

\section{Western blot analysis}

RFP (P-GP inducer) and VER (P-GP antagonist) were used as positive controls; H22/ADM cells were used as blank controls. Western blot analysis was performed as described previously [33]. After treatment with VER $10 \mu \mathrm{mol} / \mathrm{L}$, RFP $10 \mu \mathrm{mol} / \mathrm{L}$, and APS $(0.8 \mathrm{mg} / \mathrm{L}, 4 \mathrm{mg} / \mathrm{L}$, $20 \mathrm{mg} / \mathrm{L}, 100 \mathrm{mg} / \mathrm{L}, 500 \mathrm{mg} / \mathrm{L}$ ), cells were incubated for $24 \mathrm{~h}, 48 \mathrm{~h}$, or $72 \mathrm{~h}$. Cells were washed twice with icecold PBS and total cell lysates were collected in sodium dodecyl sulfate (SDS) sample buffer $(50 \mathrm{mM}$ Tris $-\mathrm{HCl}$, $\mathrm{pH}$ 6.8, $100 \mathrm{mM}$ dithiothreitol (DTT), 2\% SDS, 0.1\% bromophenol blue, $10 \%$ glycerol). Cell lysates containing equal amounts of protein were separated by SDSpolyacrylamide gel electrophoresis (PAGE) and transferred to polyvinylidine difluoride membranes. After blocking in 5\% non-fat milk in Tris-buffered saline with $0.1 \%$ Tween $20(\mathrm{pH} 7.6)$, membranes were incubated with the appropriate primary antibodies (goat antimouse IgG) at $4^{\circ} \mathrm{C}$, overnight, and exposed to the appropriate secondary antibody (goat anti-rabbit IgG) for $3 \mathrm{~h}$ at $37^{\circ} \mathrm{C}$. Immunoreactive proteins were visualized using the enhanced chemiluminescence system from Pierce (Rockford, IL, U.S.).

\section{Quantitative real time RT-PCR}

RFP (P-GP inducer) and VER (P-GP antagonist) were used as positive controls; H22/ADM cells were used as blank controls. Then $5 \times 10^{4} / \mathrm{ml} \mathrm{H} 22 / \mathrm{ADM}$ cells were seeded and incubated for $6 \mathrm{~h}$ until adherent. The cells were treated with VER $10 \mu \mathrm{mol} / \mathrm{L}$, RFP $10 \mu \mathrm{mol} / \mathrm{L}$, and APS $(0.8 \mathrm{mg} / \mathrm{L}, 4 \mathrm{mg} / \mathrm{L}, 20 \mathrm{mg} / \mathrm{L}, 100 \mathrm{mg} / \mathrm{L}, 500 \mathrm{mg} / \mathrm{L})$ and then incubated for $24 \mathrm{~h}, 48 \mathrm{~h}$, or $72 \mathrm{~h}$. Each set of exposure conditions for mRNA analysis was reproduced and confirmed by two additional independent experiments, representing biological triplicates.

MDR1 mRNA expression in H22/ADM cells was detected by quantitative RT-PCR. Total RNA was extracted using the TRIZOL reagent according to the manufacturer's instructions and reverse-transcribed to cDNA using a Gene Amp RNA PCR kit in a DNA thermal cycler (Bio-Rad). QRT-PCR was performed with SYBR green PCR master mix in an ABI Prism 7700 real time PCR machine (Applied Biosystems, Foster City, CA, U.S.). The synthesized cDNA served as a template in a $(25 \mu \mathrm{L})$ reaction. A non-template control was included in all experiments. Primer sequences are as follows: P-GP, sense: 5'-TAA TGC GAC AGG AGA TAG GCT-3', and antisense: 5'-CCG CCA TTG ACT 
GAA AGA ACA T-3'; GAPDH: sense: 5'-GAG TCA ACG GAT TTG GTC G-3', and antisense: 5'-CGG AAG ATG GTG ATG GGA TT-3'. QRT-PCR was performed at $94^{\circ} \mathrm{C}$ for $4 \mathrm{~min}$, followed by 40 cycles at $94^{\circ} \mathrm{C}$ for $15 \mathrm{~s}, 60^{\circ} \mathrm{C}$ for $25 \mathrm{~s}$, and $72^{\circ} \mathrm{C}$ for $25 \mathrm{~s}$. Data were analyzed with sequence detector software (v1.9, Applied Biosystems). The mean $\mathrm{Ct}$ value for duplicate measurements was used to detect the expression of the target gene with normalization to a housekeeping gene used as an internal control (glyceraldehyde-3-phosphate dehydrogenase GAPDH) according to the $2-\Delta \mathrm{Ct}$ formula.

\section{Statistical analysis}

Statistical analysis for the data of cell cytotoxicity, P-GP function and expression assays were performed on SPSS 14.0 software (v14, SPSS Inc. Chicago, IL, U.S.). The differences in variables between the groups were analyzed by one-way ANOVA. Real-time PCR data were analyzed using the SDS software on the ABI PRISM ${ }^{\circledR} 7700$ sequence detection system. The confidence limit was set at $95 \%$. Values of $P<0.05$ were considered statistically significant.

\section{Results}

\section{Effects of APS on H22/ADM cell proliferation}

Table 1 shows that the inhibition rates of APS ranged from $1.11 \%$ to $62.40 \%$ in a concentration-dependent manner. However, the maximum inhibition rate was only $62.40 \%$. The IC50 value of APS was $251.77 \mathrm{mg} / \mathrm{L}$, which is significantly higher than the positive control DDP $[\mathrm{IC} 50=0.04 \mathrm{mg} / \mathrm{L}](P<0.05)$.

\section{MTT assay of sensitivity of chemotherapeutic drugs}

The IC50 of different concentrations of APS combined with chemotherapeutic drugs (ADM, 5-Fu, DDP, VP-16, VCR, or CTX) and the control group (ADM, 5-Fu, DDP, VP-16, VCR, or CTX, when applied alone) are shown in Figure 1. The difference between APS combined with
ADM or VCR and the control group was not significant at APS $0.8 \mathrm{mg} / \mathrm{L}$, but APS combined with ADM or VCR could was found to significantly reduce the IC50 value $(P<0.05$, VS. control group) at APS concentrations of 4-500 mg/L; APS combined with 5-Fu, DDP, VP-16, or CTX was found to significantly reduce the IC50 value $(P<0.05$, VS. control group) at APS concentrations of 0.8-500 mg/L. For APS combined with chemotherapeutic drugs (ADM, 5-Fu, DDP, VCR, or CTX), the IC50 value decreased with increasing concentrations of APS within the range of $0.8-500 \mathrm{mg} / \mathrm{L}$, and for APS combined with VP-16, the IC50 value decreased trend with increasing concentrations of APS was not obvious.

\section{Rh-123 accumulation assay}

Rh-123 retention was measured to evaluate the P-GP transport activity in the H22/ADM cells. The fluorescent dye Rh-123 is a substrate of P-GP, and its cellular retention has been shown to reflect P-GP function. Rh-123 efflux was measured by counting cells in the M1 region of the plot. The marker bar M1 was set to indicate cells with high Rh-123 efflux. Marker bar M2 was set to indicate the cells with low Rh-123 efflux. As shown in Figure 2, compared with the control group, the RFP group fluorescence curve shifted to the left, suggesting that intracellular Rh-123 uptake decreased and P-GP efflux increased; the fluorescence curves of the APS (APS $0.8 \mathrm{mg} / \mathrm{L}$, APS $4 \mathrm{mg} / \mathrm{L}$, APS $20 \mathrm{mg} / \mathrm{L}$, APS $100 \mathrm{mg} / \mathrm{L}$, APS $500 \mathrm{mg} / \mathrm{L}$ ) and VRE groups shifted to the right, suggesting that intracellular Rh-123 retention increased and P-GP efflux function decreased over the $24 \mathrm{~h}, 48 \mathrm{~h}$, and $72 \mathrm{~h}$ time periods. However, this was only a general trend, no shifts were obvious for the RFP group or the $0.8 \mathrm{mg} / \mathrm{L}$ at $72 \mathrm{~h}$.

Table 2 shows the intracellular fluorescence intensity of Rh-123 accumulation in H22/ADM cells after exposure to chemotherapeutic agents at $24 \mathrm{~h}, 48 \mathrm{~h}$, and $72 \mathrm{~h}$. The intensity of the intracellular fluorescence of Rh-123

Table 1 Impact of APS on H22/ADM cell proliferation $(n=6)$

\begin{tabular}{|c|c|c|c|c|c|}
\hline Agents & Concentration (mg/L) & OD Value (mean $\pm S D)$ & Inhibition Rate (\%) & IC50 (mg/L) & $\mathrm{IC} 50$ 95\%Cl (mg/L) \\
\hline \multirow[t]{5}{*}{ APS } & 0.8 & $0.71 \pm 0.15$ & 1.11 & & \\
\hline & 4 & $0.67 \pm 0.12$ & 6.69 & & \\
\hline & 20 & $0.61 \pm 0.09$ & 15.04 & $251.77^{\star}$ & $1.6 \times 10-1.2 \times 10^{3}$ \\
\hline & 100 & $0.47 \pm 0.04$ & 34.54 & & \\
\hline & 500 & $0.27 \pm 0.14$ & 62.40 & & \\
\hline \multirow[t]{3}{*}{ DDP } & 0.1 & $0.29 \pm 0.02$ & 59.61 & & \\
\hline & 1.0 & $0.21 \pm 0.04$ & 70.75 & 0.04 & $1.7 \times 10^{-3}-0.74$ \\
\hline & 10 & $0.06 \pm 0.03$ & 91.64 & & \\
\hline NS & & $1.018 \pm 1.06$ & ND & & \\
\hline DMSO & 0.1 & $0.918 \pm 0.134$ & ND & & \\
\hline
\end{tabular}

${ }^{\star} P<0.05$, vs. DDP; ND: Not calculated; SD: Standard deviation; NS: normal saline. 


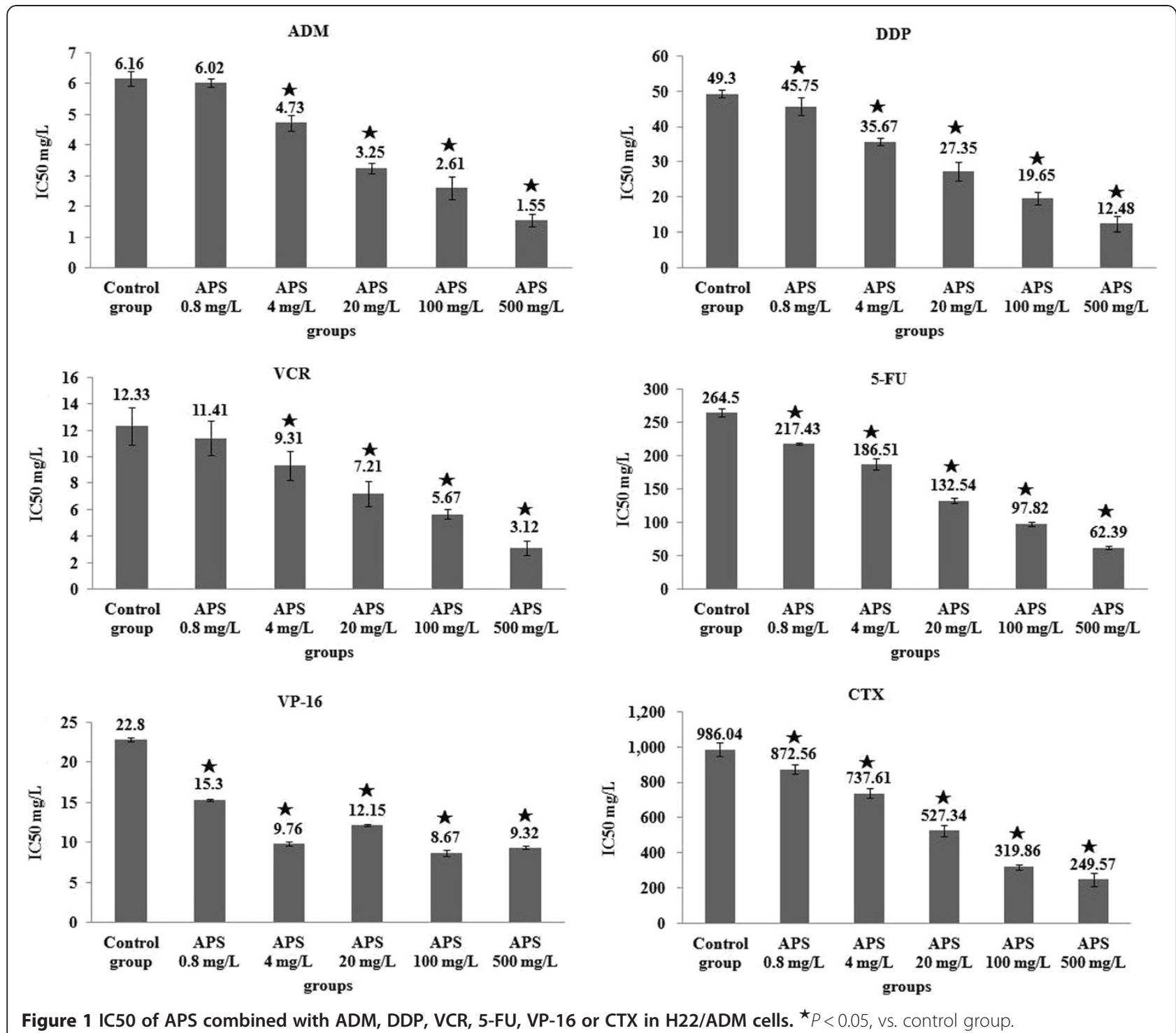

was lower in RFP $10 \mu \mathrm{mol} / \mathrm{L}$ group than in the control group, and the intensity of the intracellular fluorescence of Rh-123 was higher in VRE and APS groups than in the control group at $24 \mathrm{~h}, 48 \mathrm{~h}$, and $72 \mathrm{~h}$. The intensity of the intracellular fluorescence of Rh-123 increased with increasing concentrations of APS within the range of $0.8-500 \mathrm{mg} / \mathrm{L}$. The difference between the APS $0.8 \mathrm{mg} / \mathrm{L}$ group and the control group was not significant at $72 \mathrm{~h}$, but other APS groups saw significant increases $(P<0.05$, VS. control group) in the intensity of intracellular fluorescence of Rh-123 at $24 \mathrm{~h}, 48 \mathrm{~h}$, and $72 \mathrm{~h}$. The results show that P-GP efflux activity was inhibited by APS.

\section{Western blot analysis H22/ADM cell P-GP expression}

The protein levels of P-GP in H22/ADM cell lines were detected by Western blotting. As indicated in Figure 3, the level of P-GP protein was lower in the APS (APS $0.8 \mathrm{mg} / \mathrm{L}$, APS $4 \mathrm{mg} / \mathrm{L}$, APS $20 \mathrm{mg} / \mathrm{L}$, APS $100 \mathrm{mg} / \mathrm{L}$, APS $500 \mathrm{mg} / \mathrm{L}$ ) and VER groups than in the H22/ADM group at $24 \mathrm{~h}, 48 \mathrm{~h}$, and $72 \mathrm{~h}$. The protein level of P-GP was higher in the RFP group compared to H22/ADM group at $24 \mathrm{~h}, 48 \mathrm{~h}$, and $72 \mathrm{~h}$ time points. The same concentration of APS affected P-GP expression in different ways at different times. P-GP expression was largest at $24 \mathrm{~h}$ and then fell in a time-dependent manner. Different concentrations of APS were found to down regulate P-GP expression with increasing concentrations of APS in a concentration-dependent manner in the range of $0.8-500 \mathrm{mg} / \mathrm{L}$. These results showed that APS could down regulate P-GP expression in a concentration-dependent manner within the range of 0.8-500 $\mathrm{mg} / \mathrm{L}$ and in a time-dependent manner from $24 \mathrm{~h}$ to $72 \mathrm{~h}$. 


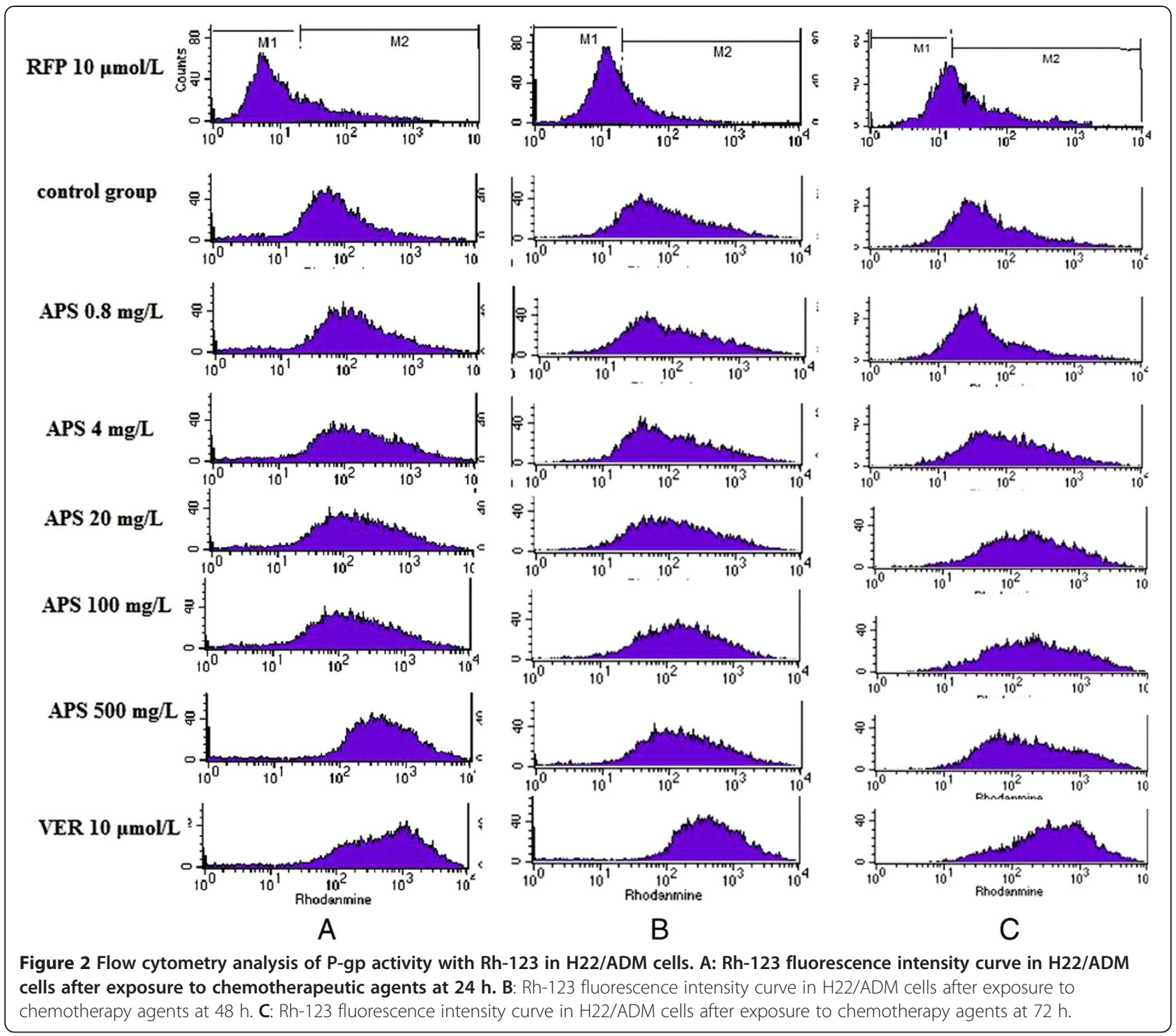

\section{Quantitative RT-PCR detection of MDR1 mRNA in H22/ ADM cells}

After intervention for $24 \mathrm{~h}, 48 \mathrm{~h}$, and $72 \mathrm{~h}$, the levels of MDR1 mRNA expression in H22/ADM cells were detected by quantitative RT-PCR. As indicated in Table 3, the levels of MDR1 mRNA expression decreased $(P<0.05)$ in APS (APS $0.8 \mathrm{mg} / \mathrm{L}$, APS $4 \mathrm{mg} / \mathrm{L}$, APS $20 \mathrm{mg} / \mathrm{L}$, APS $100 \mathrm{mg} / \mathrm{L}$, APS $500 \mathrm{mg} / \mathrm{L}$ ) and VER groups compared to H22/ADM group at $24 \mathrm{~h}, 48 \mathrm{~h}$, and $72 \mathrm{~h}$ time points; the levels of MDR1 mRNA expression were higher in the RFP group than in the H22/ADM group at $24 \mathrm{~h}, 48 \mathrm{~h}$ and $72 \mathrm{~h}$. MDR1 mRNA expression decreased with increasing concentrations of APS within the range of $0.8-500 \mathrm{mg} / \mathrm{L}$.

Existing data on the relationship between mRNA and protein levels create a somewhat contradictory picture, as shown in Figure 2 and Table 3. For example, there is no correlation between time dependent changes in the MDR1 mRNA levels and corresponding P-GP levels. This merits further study.

\section{Discussion}

The dried root of Astragalus membranaceus has a long history of medicinal use in TCM. It is an adjunct anticancer agent and it has been the subject of a great deal of research $[17,22,24]$. Studies have shown that APS has anti-tumor activity in vitro when applied alone in certain tumor cell lines, such as murine renal cell carcinoma, murine bladder tumors, HepG2 cells, human gastric cancer SCG-7901 cells, human colon cancer cell lines, hormone-sensitive (MCF-7) breast cancer cell lines, and human hepatocellular carcinoma [13,17,24,25,29,30]. Animal tumor models and clinical studies have also confirmed that APS has anti-tumor activity [16,21-23,34]. 
Table 2 Intracellular fluorescence intensity of Rh-123 accumulation in H22/ADM cells $(n=6)$

\begin{tabular}{|c|c|c|c|}
\hline \multirow[t]{2}{*}{ Group } & \multicolumn{3}{|c|}{ Fluorescence intensity (mean \pm SD) } \\
\hline & $24 \mathrm{~h}$ & $48 \mathrm{~h}$ & $72 \mathrm{~h}$ \\
\hline RFP $10 \mu \mathrm{mol} / \mathrm{L}$ & $87.49 \pm 1.26^{\star}$ & $133.71 \pm 1.59^{\mathbf{\Lambda}}$ & $131.41 \pm 1.54$ \\
\hline Control group & $114.77 \pm 1.16$ & $198.51 \pm 0.69$ & $136.18 \pm 1.32$ \\
\hline APS 0.8 mg/L & $135.52 \pm 0.92^{\star}$ & $255.14 \pm 0.61^{\wedge}$ & $137.40 \pm 2.01$ \\
\hline APS $4 \mathrm{mg} / \mathrm{L}$ & $257.38 \pm 0.97^{\star}$ & $266.32 \pm 2.03$ & $250.32 \pm 1.80^{\bullet}$ \\
\hline APS $20 \mathrm{mg} / \mathrm{L}$ & $357.34 \pm 0.80^{\star}$ & $285.75 \pm 1.30^{\mathbf{\Lambda}}$ & $367.35 \pm 1.31$ \\
\hline APS $100 \mathrm{mg} / \mathrm{L}$ & $342.83 \pm 0.94^{\star}$ & $307.42 \pm 1.12^{\boldsymbol{\Perp}}$ & $460.04 \pm 1.74$ \\
\hline APS $500 \mathrm{mg} / \mathrm{L}$ & $701.30 \pm 1.14^{\star}$ & $345.27 \pm 1.84$ & $458.43 \pm 0.63$ \\
\hline VER $10 \mu \mathrm{mol} / \mathrm{L}$ & $928.04 \pm 1.17^{\star}$ & $706.04 \pm 2.02$ & $657.91 \pm 1.28$ \\
\hline
\end{tabular}

${ }^{\star} P<0.05$, vs. Control group (24 h); ${ }^{\mathbf{\wedge}} P<0.05$, vs. Control group (48 h);

- $P<0.05$, vs. Control group (72 h).

However, there have only been a few reports of the treatment of drug-resistant tumor cells with APS. The present study shows at a final concentration range of $0.8-500 \mathrm{mg} / \mathrm{L}$, the IC50 value of APS for H22/ADM cell proliferation was $251.77 \mathrm{mg} / \mathrm{L}$. According to National Cancer Institute guidelines, extracts with IC50values $<20 \mu \mathrm{g} / \mathrm{ml}$ are considered active in vitro [35]. The results show that that APS has no antitumor activity for H22/ADM cells in vitro when applied alone. However, patients with advanced cancer can be treated with APS combined with chemotherapeutic drugs. It has been found to inhibit tumor development, decrease the toxic-adverse effects of chemotherapy, elevate immune function, and improve patient quality of life [34-36]. For example, Guo et al. reported that treatment with APS injections integrated with vinorelbine and cisplatin significantly improved quality of life in patients with advanced nonsmall-cell lung cancer over vinorelbine and cisplatin alone [23]. Animal tumor models and in vitro studies confirmed that APS can enhance the chemo-sensitivity of the chemotherapy drugs for non-drug-resistant tumor cells [37-39]. For example, Li et al. reported that the weight of tumors in subjects treated with APS and ADM was significantly lower
Table 3 MDR1 mRNA expression in H22/ADM cells at different times (24 h, 48 h, 72 h) $(n=6)$

\begin{tabular}{|c|c|c|c|}
\hline \multirow[t]{2}{*}{ Group } & \multicolumn{3}{|c|}{$2-\triangle \triangle$ Ct $($ Mean \pm SD) } \\
\hline & $24 \mathrm{~h}$ & $48 \mathrm{~h}$ & $72 \mathrm{~h}$ \\
\hline RFP $10 \mu \mathrm{mol} / \mathrm{L}$ & $1.670 \pm 0.027$ & $1.977 \pm 0.064$ & $2.726 \pm 0.086$ \\
\hline H22/ADM & $1.525 \pm 0.039$ & $1.797 \pm 0.108$ & $2.563 \pm 0.048$ \\
\hline VER $10 \mu \mathrm{mol} / \mathrm{L}$ & $0.519 \pm 0.045^{\star}$ & $0.497 \pm 0.107^{\boldsymbol{\Perp}}$ & $0.440 \pm 0.114^{\bullet}$ \\
\hline APS 500 mg/L & $0.616 \pm 0.035^{\star}$ & $0.565 \pm 0.033^{\wedge}$ & $0.496 \pm 0.072^{\bullet}$ \\
\hline APS 100 mg/L & $0.792 \pm 0.163^{\star}$ & $0.742 \pm 0.077^{\boldsymbol{\Perp}}$ & $0.898 \pm 0.042^{\bullet}$ \\
\hline APS $20 \mathrm{mg} / \mathrm{L}$ & $0.890 \pm 0.055^{\star}$ & $1.067 \pm 0.107^{\boldsymbol{\Lambda}}$ & $1.076 \pm 0.108^{\bullet}$ \\
\hline APS $4 \mathrm{mg} / \mathrm{L}$ & $1.128 \pm 0.051^{\star}$ & $1.183 \pm 0.058^{\wedge}$ & $1.412 \pm 0.027^{\bullet}$ \\
\hline APS $0.8 \mathrm{mg} / \mathrm{L}$ & $1.260 \pm 0.113^{\star}$ & $1.406 \pm 0.024^{\boldsymbol{\Lambda}}$ & $1.736 \pm 0.063^{\bullet}$ \\
\hline
\end{tabular}

$\star^{\star} P<0.05$, vs. H22/ADM group (24 h); ${ }^{\mathbf{\Delta}} P<0.05$, vs. H22/ADM group (48 h);

- $P<0.05$, vs. H22/ADM group (72 h).

than those of the NS group [16]. Cui R. et al. reported that hepatocarcinogenesis could be prevented in rats fed with the aqueous extract of Astragalus, which is mainly composed of Astragalus polysaccharides [21]. For H22/ADM resistant cells, as shown in Figure 1 that APS combined with ADM or VCR could significantly reduce the IC50 value $(P<0.05$, VS. control group) at APS concentration range of $4 \mathrm{mg} / \mathrm{L}$ to $500 \mathrm{mg} / \mathrm{L}$; APS combined with 5-Fu, DDP, VP-16, or CTX could significantly reduce the IC50 value $(P<0.05$, VS. control group) at APS concentration range of $0.8-500 \mathrm{mg} / \mathrm{L}$. In this way, APS can enhance the chemo-sensitivity of the most common chemotherapy drugs in vitro. The present results were partially supported by the results of the abovementioned studies.

Those research teams speculated that the anti-tumor activity of APS might involve enhancement of immune function and induction of apoptosis. However, the mechanism underlying these effects remains to be determined. Changweiqing (Radix Astragali, Radix Codonopsis, Rhizoma Atraety lodis macroce phalae) was found to reverse the drug resistance of colon cancer cells by reducing the expression of MDR1/P-GP [25]. APS is the

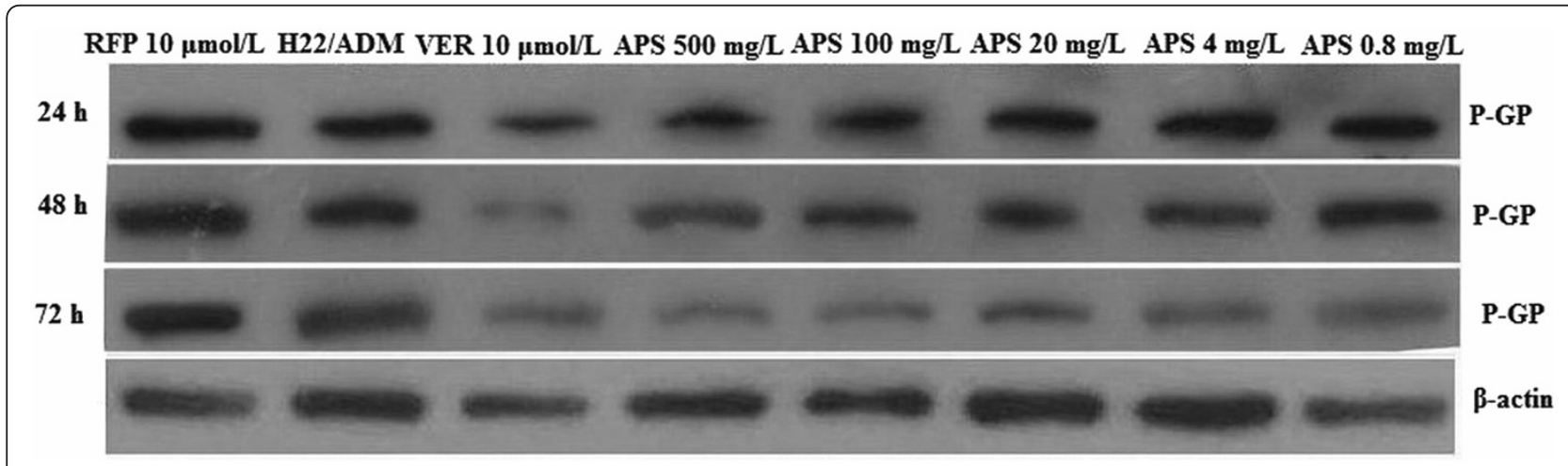

Figure 3 P-GP expressions in H22/ADM cells after exposure to the different chemotherapy agents at different time points ( $24 \mathrm{~h}, 48 \mathrm{~h}$, and $72 \mathrm{~h}$ ). 
main active ingredient of Radix Astragali, its involvement in the reversal of MDR merits further investigation $[13,14]$.

Drug resistance in tumor cells has been shown to be related to MDR1 and P-GP overexpression [40-42]. In the present study, APS was found to enhance the chemosensitivity of H22/ADM cell lines to certain drugs. To determine whether APS is involved in P-GP expression and/or its efflux function, the P-GP inducer RFP and P-GP inhibitor VER were used as positive controls, and an H22/ADM group was used as a blank control.

$\mathrm{Rh}-123$ is a cationic dye. It has been used extensively as a marker of P-GP-mediated transport in both in vitro and in vivo studies [43-47]. In the present study, the intracellular fluorescence intensity of Rh-123 increased with increasing concentrations of APS in a concentrationdependent manner in the range of $0.8-500 \mathrm{mg} / \mathrm{L}$. The results show that P-GP efflux activity was inhibited by APS.

Western blot analysis of P-GP expression and quantitative RT-PCR detection of MDR1 mRNA expression in H22/ADM cell lines showed that APS reduced P-GP protein expression and MDR1 mRNA expression in a concentration-dependent manner within the range of 0.8-500 $\mathrm{mg} / \mathrm{L}$ and in time-dependent manner from $24 \mathrm{~h}$ to 72 h. APS not only inhibited P-GP efflux but also reduced P-GP and MDR1 mRNA expression in a concentration-dependent manner. However, this effect was not uniform across all times. For example, APS inhibition of P-GP efflux function did not occur in a time-dependent manner; and there was no visible correlation between time-dependent changes in the MDR1 mRNA levels and corresponding P-GP levels. The modest correlation between mRNA expression and protein abundance in large-scale data sets can be explained in part by experimental challenges, such as technological limitations, and in part by fundamental biological factors in the transcription and translation processes. Translation is a complicated biological process, and many of the details still merit further investigation. For example, highly expressed proteins may not necessarily require large quantities of mRNA if they have higher than average translation rates. This merits further study [48].

Drug resistance is a major obstacle to the successful treatment of cancer. Tumor cells either fail to reduce in size following chemotherapy or cancer recurs. The phenomenon of MDR is particularly problematic because it involves the simultaneous resistance to numerous chemotherapeutics of different classes, and the mechanism by which tumors develop MDR is very complex, P-GP overexpression is one important factor in this process [49]. Studies have shown that APS has anti-tumor activity in certain tumor cell lines in vitro and in animal models of certain tumors. The present study confirmed that APS can downregulate MDR1 mRNA expression, inhibit P-GP efflux function and decrease its expression, thereby increasing the intracellular concentration of chemotherapeutic drugs. This may be the mechanism behind its secondary anti-cancer effects.

It has been reported that APS can increase the sensitivity of chemotherapeutics, reducing the side effects and complications associated with chemotherapy, and improve patient quality of life and survival time $[12,14,19,20,23]$. In this way, in the search for new cancer therapeutics with minimal toxicity and few side effects, APS is a promising candidate.

\section{Conclusion}

In summary, APS was found to enhance the chemosensitivity of the H22/ADM cell line, which may be related to downregulation of MDR1 mRNA expression and inhibition of P-GP efflux pump function, which decreases its MDR1 protein expression.

\section{Abbreviations}

MDR: Multidrug resistance; H22/ADM: H22 hepatoma resistant to adriamycin cell lines; P- GP: P-glycoprotein; TCM: Traditional Chinese medicine; APS: Astragalus polysaccharides; MTX: Cyclophosphamid; ADM: Adriamycin; 5-Fu: 5-fluorouracil; DDP: Cisplatin; VP-16: Etoposide; VCR: Vincristine; VER: Verapamil; RFP: Rifampicin; NS: Normal salin; DMSO: DimeThyl sulfoxide; OD: Optical density; $I_{50}$ : Half inhibitory concentration; GAPDH: Glyceraldehyde-3-phosphate dehydrogenase.

\section{Competing interests}

The authors declare that they have no competing interests.

\section{Authors' contributions}

QET has made substantial contributions to conception and design, acquisition of data, analysis and interpretation of data, and drafted the manuscript; HDL has made substantial contributions to conception and design; MY, H-LC, Q-YT and W-YZ have been involved in drafting the manuscript and revising it critically for important intellectual content. All authors read and approved the final manuscript.

\section{Author details}

${ }^{1}$ Clinical Pharmacy and Pharmacology Research Institute, The Second Xiangya Hospital, Central South University, 139 Renmin Middle Road, Changsha, Hunan 410011, China. ${ }^{2}$ School of Pharmaceutical Sciences, Central South University, Changsha, Hunan 410011, China. ${ }^{3}$ Xiangtan Central Hospital, Xiangtan, Hunan 411100, China.

Received: 5 March 2012 Accepted: 15 June 2012

Published: 11 July 2012

\section{References}

1. Lancet T: Moving cancer up the global health agenda. Lancet 2010, 375(9731):2051.

2. The World Health Report 2008 - primary health care: Now more than ever. http://www.who.int/whr/2008/whr08_en.pdf.

3. Urruticoechea A, Alemany R, Balart J, Villanueva A, Viñals F, Capellá G: Recent advances in cancer therapy: an overview. Curr Pharm Des 2010, 16(1):3-10.

4. Kellof GJ: Perspective on cancer chemoprevention research and drug development. Adv Cancer Res 2000, 78:199-334.

5. Choi $\mathrm{CH}: \mathrm{ABC}$ transporters as multidrug resistance mechanisms and the development of chemosensitizers for their reversal. Cancer Cell Int 2005, 5:30. 
6. Nobili S, Landini I, Giglioni B, Mini E: Pharmacological strategies for overcoming multidrug resistance. Curr Drug Targets 2006, 7(7):861-879.

7. Wong R, Sagar CM, Sagar SM: Integration of Chinese medicine into supportive cancer care: a modern role for an ancient tradition. Cancer Treat Rev 2001, 27(4):235-246.

8. Qi F, Li A, Inagaki Y, Gao J, Li J, Kokudo N, Li XK, Tang W: Chinese herbal medicines as adjuvant treatment during chemo- or radio-therapy for cancer. Biosci Trends 2010, 4(6):297-307.

9. Ruan WJ, Lai MD, Zhou JG: Anticancer effects of Chinese herbal medicine, science or myth? J Zhejiang Univ Sci B 2006, 7(12):1006-1014.

10. Konkimalla VB, Efferth T: Evidence-based Chinese medicine for cancer therapy. J Ethnopharmacol 2008, 116(2):207-210.

11. Ji DB, Ye J, Jiang YM, Qian BW: Anti-tumor effect of Liqi, a traditional Chinese medicine prescription, in tumor bearing mice. BMC Complement Altern Med 2009, 9:20.

12. Balch PA: Prescription for Nutritional Healing, A Practical A-to-Z Reference to Drug-Free Remedies Using Vitamins, Minerals, Herbs and Food Supplements. 5th edition. New York, NY, USA: Avery Penguin Putnam Inc.; 2006.

13. Rittenhouse JR, Lui PD, Lau BH: Chinese medicinal herbs reverse macrophage suppression induced by urological tumors. J Urol 1991 146(2):486-490.

14. Ma XQ, Shi Q, Duan JA, Dong TT, Tsim KW: Chemical analysis of Radix Astragali (Huangqi) in China: a comparison with its adulterants and seasonal variations. J Agric Food Chem 2002, 50(17):4861-4866.

15. Shao BM, Xu W, Dai H, Tu P, Li Z, Gao XM: A study on the immune receptors for polysaccharides from the roots of Astragalus membranaceus, a Chinese medicinal herb. Biochem Biophys Res Commun 2004, 320(4):1103-1111.

16. Li J, Bao Y, Lam W, Li W, Lu F, Zhu X, Liu J, Wang H: Immunoregulatory and anti-tumor effects of polysaccharopeptide and Astragalus polysaccharides on tumor-bearing mice. Immunopharmacol Immunotoxicol 2008, 30(4):771-782.

17. Liu X, Yang Y, Zhang X, Xu S, He S, Huang W, Roberts MS: Compound Astragalus and Salvia miltiorrhiza extract inhibits cell invasion by modulating transforming growth factor-beta/Smad in HepG2 cell. J Gastroenterol Hepatol 2010, 25(2):420-426.

18. Zhao LH, Ma ZX, Zhu J, Yu XH, Weng DP: Characterization of polysaccharide from Astragalus radix as the macrophage stimulator. Cell Immunol 2011, 271(2):329-334.

19. World Health Organization (WHO): Medicinal Plants in China. Manila: WHO Regional Publications; 1989

20. Zee-Cheng RK: Shi-quan-da-bu-tang (ten signifcant tonic decoction), SQT. A potent Chinese biological response modifier in cancer immunotherapy, potentiation and detoxification of anticancer drugs. Methods Find Exp Clin Pharmacol 1992, 14(9):725-736

21. Cui R, He J, Wang B, Zhang F, Chen G, Yin S, Shen H: Suppressive effect of Astragalus membranaceus Bunge on chemical hepatocarcinogenesis in rats. Cancer Chemother Pharmacol 2003, 51(1):75-80.

22. Wang J, Ito H, Shimura K: Enhancing effect of antitumor polysaccharide from Astragalus or Radix hedysarum on C3 cleavage production of macrophages in mice. Jpn J Pharmacol 1989, 51(3):432-434.

23. Guo L, Bai SP, Zhao L, Wang XH: Astragalus polysaccharide injection integrated with vinorelbine and cisplatin for patients with advanced non-small cell lung cancer: effects on quality of life and survival. Med Oncol. http://dx.doi.org/10.1007/s12032-011-0068-9.

24. Liu XN, Zhang CY, Jin XD, Li YZ, Zheng XZ, Li L: Inhibitory effect of schisandrin B on gastric cancer cells in vitro. World J Gastroenterol 2007, 13(48):6506-6511.

25. $\mathrm{Xu} \mathrm{JH}$, Deng WL, Fan ZZ: Effects of changwelqing on nuclear translocation of $\mathrm{Y}$-box binding protein-1 and expregslon of $\mathrm{P}$ glycoprotein in human colon cancer cell line with drug-resistance induced by vincristine. Zhongguo Zhong Xi Yi Jie He Za Zhi 2010, 30(7):743-747

26. An HJ, Wang XY, Yu M, Sheng J, Li PT, Zhang B: Influence of preventing formula for UC on P-gp level in colon tissue of ulcerative colitis in rats. Journal of TCM Univ. of Hunan 2009, 29(4):15-17.

27. Huang $\mathrm{CH}$, Xie ZX, Qin Q: The mechanism of Chinese medicine compound jiexinkang to reverse the multidrug resistance of K562/A02 cells. Journal of TCM Univ. of Hunan 2004, 24(1):7-10.
28. Zhang $G$, Shi L, Selke M, Wang X: CdTe quantum dots with daunorubicin induce apoptosis of multidrug-resistant human hepatoma HepG2/ADM cells: in vitro and in vivo evaluation. Nanoscale Res Lett 2011, 6(1):418.

29. Zhou RF, Liu PX, Tan M: Effect of Astragalus mongholicus injection on proliferation and apoptosis of hormone sensitive (MCF-7) breast cancer cell lines with physiological dose E2. Zhong Yao Cai 2009, 32(5):744-747

30. Li Q, Bao JM, Li XL, Zhang T, Shen XH: Inhibiting effect of Astragalus polysaccharides on the functions of CD4 + CD25 highTreg cells in the tumor microenvironment of human hepatocellular carcinoma. Chin Med $J$ (Engl) 2012, 125(5):786-793.

31. Yang M, Qian XH, Zhao DH, Fu SZ: Effects of Astragalus polysaccharide on the erythroid lineage and microarray analysis in K562 cells. J Ethnopharmacol 2010, 127(2):242-250.

32. Collett A, Tanianis-Hughes J, Warhurst G: Rapid induction of Pglycoprotein expression by high permeability compounds in colonic cells in vitro: a possible source of transporter mediated drug interactions? Biochem Pharmacol 2004, 68(4):783-790.

33. Mi Y, Lou L: ZD6474 reverses multidrug resistance by directly inhibiting the function of P-glycoprotein. Br J Cancer 2007, 97(7):934-940.

34. Cassileth BR, Rizvi N, Deng G, Yeung KS, Vickers A, Guillen S, Woo D, Coleton M, Kris MG: Safety and pharmacokinetic trial of docetaxel plus an Astragalus-based herbal formula for non-small cell lung cancer patients. Cancer Chemother Pharmacol 2009, 65(1):67-71.

35. Duan $P$, Wang ZM: Clinical study on effect of Astragalus in efficacy enhancing and toxicity reducing of chemotherapy in patients of malignant tumor. Zhongguo Zhong Xi Yi Jie He Za Zhi 2002, 22(7):515-517.

36. Zou YH, Liu XM: Effect of astragalus injection combined with chemotherapy on quality of life in patients with advanced non-small cell lung cancer. Zhongguo Zhong Xi Yi Jie He Za Zhi 2003, 23(10):733-735

37. Zhang ZX, Qi F, Zhou DJ, Liang XY, Zhu LW, Wang PZ: Effect of 5fluorouracil in combination with Astragalus membranaceus on amino acid metabolism in mice model of gastric carcinoma. Zhonghua Wei Chang Wai Ke Za Zhi 2006, 9(5):445-447.

38. Cho WC, Leung KN: In vitro and in vivo anti-tumor effects of Astragalus membranaceus. Cancer Lett 2007, 252(1):43-54.

39. Boyed MR: The $\mathrm{NCl}$ in vitro anticancer drug discovery screen. In Anticancer drug development guide; preclinical screening, clinical trials and approval. Edited by Teicher B. Totowa: Humana Press; 1997:30.

40. Dizdarevic S, Peters AM: Imaging of multidrug resistance in cancer. Cancer Imaging 2011, 11:1-8.

41. Goda K, Bacsó Z, Szabó G: Multidrug resistance through the spectacle of P-glycoprotein. Curr Cancer Drug Targets 2009, 9(3):281-297.

42. Mayur YC, Peters GJ, Prasad W, Lemo C, Sathish NK: Design of new drug molecules to be used in reversing multidrug resistance in cancer cells. Curr Cancer Drug Targets 2009, 9(3):298-306.

43. Li H, Yan Z, Ning W, Xiao-Juan G, Cai-Hong Z, Jin-Hua J, Fang M, Qing-Duan W: Using rhodamine 123 accumulation in CD8 cells as a surrogate indicator to study the P-glycoprotein modulating effect of cepharanthine hydrochloride in vivo. J Biomed Biotechnol 2011, 2011:281651.

44. Abuznait AH, Patrick SG, Kaddoumi A: Exposure of LS-180 cells to drugs of diverse physicochemical and therapeutic properties up-regulates P-glycoprotein expression and activity. J Pharm Pharm Sci 2011, 14(2):236-248.

45. Kawami M, Yumoto R, Nagai J, Junyaprasert VB, Soonthornchareonnon N, Patanasethanont D, Sripanidkulchai BO, Takano M: Effect of Thai plant extracts on P-glycoprotein function and viability in paclitaxel-resistant HepG2 cells. Drug Metab Pharmacokinet 2010, 25(2):155-162.

46. Yumoto R, Murakami T, Sanemasa M, Nasu R, Nagai J, Takano M: Pharmacokinetic interaction of cytochromeP450 3A-related compounds with rhodamine 123, a P-glycoprotein substrate, in rats pretreated with dexamethasone. Drug Metab Dispos 2001, 29(2):145-151.

47. Naud J, Michaud J, Leblond FA, Lefrancois S, Bonnardeaux A, Pichette V: Effects of chronic renal failure on liver drug transporters. Drug Metab Dispos 2008, 36(1):124-128.

48. Nie L, Wu G, Zhang W: Correlation of mRNA expression and protein abundance affected by multiple sequence features related to 
translational efficiency in Desulfovibrio vulgaris: a quantitative analysis. Genetics 2006, 174(4):2229-2243.

49. Gong J, Jaiswal R, Mathys JM, Combes V, Grau GE, Bebawy M:

Microparticles and their emerging role in cancer multidrug resistance. Cancer Treat Rev 2012, 38(3):226-234.

doi:10.1186/1472-6882-12-94

Cite this article as: Tian et al:: Effects of Astragalus polysaccharides on

P-glycoprotein efflux pump function and protein expression in $\mathrm{H} 22$

hepatoma cells in vitro. BMC Complementary and Alternative Medicine 2012

12:94.

\section{Submit your next manuscript to BioMed Central} and take full advantage of:

- Convenient online submission

- Thorough peer review

- No space constraints or color figure charges

- Immediate publication on acceptance

- Inclusion in PubMed, CAS, Scopus and Google Scholar

- Research which is freely available for redistribution 